Available online at www.jmle.org

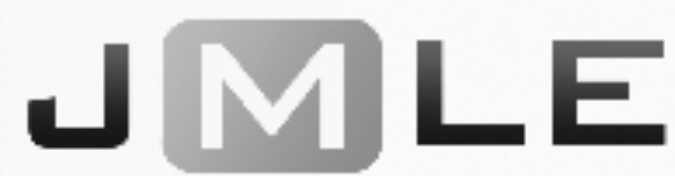

The National Association for Media Literacy Education's

Journal of Media Literacy Education 10 (1), 22 - 41

\title{
Poverty, Literacy, and Social Transformation: An Interdisciplinary Exploration of the Digital Divide
}

\author{
Amy J. Bach \\ University of Texas at El Paso \\ Todd Wolfson and Jessica K. Crowell \\ Rutgers University
}

\begin{abstract}
Harnessing scholarship focused on literacy and poverty, in this article we aim to complicate the common understanding of the digital divide. First, we argue that the dominant literature on the digital divide misses broader connections between technological exclusion and broader forms of economic and social exclusion. Accordingly, and following recent qualitative research on the digital divide, we believe future scholarship must examine the complicated relationships between poverty, inequality, and the digital divide and we look to poverty scholarship to understand the complicated and shifting nature of poverty. Finally, we make the case that scholars and practitioners focused on digital literacy programs should pay attention to historical and critical scholarship on education and its role in mediating poverty and fostering social mobility, as it serves digital divide and broadband adoption scholars to understand the ways education processes can either reproduce or set the stage to alter entrenched social realities
\end{abstract}

Keywords: poverty, digital divide, literacy, social transformation

On a cold Saturday morning in January of 2012, hundreds of unemployed and underemployed Philadelphians flocked to historic Girard College in Northwest Philadelphia to attend the Freedom Rings Partnership Digital Jobs Fair and various free workforce development workshops. The Freedom Rings Partnership - a joint venture between the City of Philadelphia, the Urban Affairs Coalition, local universities, and multiple community-based organizations - was funded through the federal Broadband Technology Opportunities Program as part of the 2009 American Recovery and Reinvestment Act, also known as the stimulus package. The goal of the Freedom Rings Partnership was to build-out and enhance 77 computer centers across the city, while training 15,000 Philadelphians in basic computer and digital literacy, to catalyze broadband adoption in low-income communities and improve employment prospects for 
Philadelphians searching for work.

For over twenty years, Girard College has served as the host of the annual Martin Luther King Day of Service, an event which features speakers and cultural celebrations, coordinates service projects and workshops across Philadelphia, and also partners with local and city organizations to promote events for job seekers, such as the Digital Jobs Fair event. Job-related events have been particularly well attended in Philadelphia, as unemployment rates increased following the 2009 economic crisis that precipitated the stimulus package. In 2012, approximately $10.7 \%$ of Philadelphians were unemployed, compared to an $8.1 \%$ unemployment rate nation-wide (Pew Charitable Trusts, 2013). Of those working, Philadelphia's rank in having one of the lowest household median incomes of all major cities in the U.S. - approximately $\$ 34,000$, or $\$ 16,000$ below the national average (Pew Charitable Trusts, 2013). This suggests a combination of lower wages and underemployment have shaped and continue to shape the landscape of employment in this city (Pew Charitable Trusts, 2016). Research by economists Lawrence Katz and Alan Krueger (as cited in Konczal, 2016) points to a nationwide growth in "alternative work arrangements" (para. 3) over the last ten years, a term that includes "temporary, on-call, contract, and independent workers" (para. 3) along with a slight decrease in employment in traditional jobs.

These types of work arrangements lead to precarious employment and lower pay for workers. While the 2009 market crash led to acute problems of joblessness, poverty, and income inequality, Philadelphia's urban crisis has been developing across the last fifty years. From deindustrialization and the growth of precarious employment (Konczal, 2016) and a service sector economy dependent on low-paying jobs (McKee, 2008), to white flight, a shrinking tax base, and widespread retrenchment of the welfare state (Katz, 2008), the difficulty of finding a job with a living wage, and correspondent social and economic problems, have become a structural feature of life in Philadelphia.

For this reason, on the day of the Martin Luther King Day of Service event, hundreds of job seekers poured into a medium-sized classroom that housed the Digital Jobs Fair where attendees without in-home Internet access were offered the opportunity to use laptops to draft emails to prospective employers or create and print their resumes. Representatives from the partnership spoke with visitors about how to search for jobs online and the benefits of in-home Internet access. A few attendees lingered to use the computers; quizzically, one woman holding a black folder asked, "Wait... are there companies here to talk to?" Following this, several job-seekers wandered down an interior corridor into classrooms where Target Corporation volunteers in branded red t-shirts led workforce development workshops on topics ranging from resume writing to building your personal brand.

After stopping at the Digital Jobs Fair and the Target event, job seekers entered a larger, crowded open space where representatives from companies including Comcast, AT\&T, Vanguard, and Piedmont Airlines were seated in rows at folding tables. A young African American man approached the Piedmont Airlines table with his printed resume in hand. The Piedmont representative told him they were not collecting resumes and he was instructed instead to "follow the 
company on Facebook and Twitter." A young woman moved toward the Comcast table and explained to the representative, "I work at a daycare center right now." Another man in a tweed baseball cap pushed through the crowd and questioned a recruiter, "You need a driver's license? Mine is suspended for a ticket." The general mood in the hall was one of anxiety, as job seekers pressed corporate representatives in order to ferret out real job opportunities in an environment where few existed.

Leaning against a back wall with a folder of freshly printed resumes, Ron, a 45-year old who recently lost his job in the healthcare sector, explained that while the companies gathered at the in-person event were "topnotch," the only positions being discussed were part-time, and most of the representatives he spoke with "were just like 'hey, let's keep going, look at the website."' When questioned about his access to a computer and his need to attain digital skills, Ron replied that he had two laptops at home, was a regular user of social media sites, and had expertise in programs like Photoshop and Illustrator. Ron then reflected on the current employment landscape in urban Philadelphia. He observed: "I think the best area to go into is some type of form of customer service, where it is high demand, low reward."

Ron's reflection, and the Digital Job Fair more generally, brings to the fore the incongruity between our collective imagination around technology and work on one hand and the real structural deficiencies of jobs and employment on the other. Out-of-work Philadelphians can re-tool their resume or learn how to use Word or Twitter, but this won't alter the job landscape in their city. The popular belief held by people in positions of power is that with new skills or a bit of tech training people can re-tool themselves and find new job opportunities is more myth then reality (see also Crowell, 2017). Vincent Mosco (2005) has called this fantasy the "digital sublime," to mark a collective fundamental need to believe in the progressive possibility embedded in technological development in order to escape the banality, or even wreckage, of everyday life.

The complexity of connected issues, from the Digital Job Fair and Ron's candid assessment, to the broader quixotic investment in technological solutions, opens a window onto a set of interrelated arguments we make in this article. First, we argue that the dominant literature on the digital divide misses broader connections between technological exclusion and broader forms of economic and social exclusion. Accordingly, and following recent qualitative research on the digital divide, we believe future scholarship must examine the relationship between poverty, inequality, and the digital divide and we look to poverty scholarship to understand the complicated and shifting nature of poverty. Finally, we make the case that scholars and practitioners focused on digital literacy programs should pay attention to historical and critical scholarship on education and its role in mediating poverty and fostering social mobility, as education processes can either reproduce or set the stage to alter entrenched social realities.

We open this article with a vignette from a Philadelphia-based ethnographic research project focused on understanding the complicated role technology access programs play in the longstanding problems of urban poverty and inequality. The authors all participated in this research (see Wolfson, Crowell, 
Reyes, \& Bach, 2017) and we begin in Philadelphia because it shines a light on some of the core questions about the intersection of poverty, inequality, and the digital divide we discuss in the article. However, the majority of this article is focused on making a theoretical intervention by pointing to the limits of the digital divide literature and discussing important ways the field can address these limitations. We conclude this paper by briefly discussing some forward-looking programs and approaches for practitioners.

\section{Mapping the Digital Divide}

It is difficult to underestimate the importance of the Internet in society today; it has revolutionized the social, political, and economic environment in which we live (Cooper, 2010) by providing an increasingly central platform for communication, gathering and disseminating information, entertainment, and education. The United Nations has declared the Internet a human right (La Rue, 2011) because it "enable[s]...a range of...human rights" (p. 1), such as "economic, social and cultural rights...the right to education and the right to take part in cultural life and to enjoy the benefits of scientific progress and its applications, as well as civil and political rights, such as the rights to freedom of association and assembly" (p. 7). Arguing that access to the Internet "should be a priority for all States" (p. 4), the UN Human Rights Council's findings parallel those of other scholars and community leaders ${ }^{1}$ that social and economic inclusion in society today increasingly requires access to the Internet. As more and more core services have migrated online, the benchmark for digital inclusion has also shifted; dial-up and cell phone-based Internet access offer an inadequate level of access to the sheer mass of modern webtexts and the array of societal services that have shifted to online platforms make high-speed Internet access, or broadband access, the new the basic standard (Dailey, Byrne, Powell, Karaganis, \& Chung, 2010).

Recognizing the growing importance of the Internet, research on the digital divide has mapped the landscape of access. Structural factors found to influence the adoption or non-adoption of high-speed Internet services include its prohibitive cost (Digital Impact Group, 2009; Horrigan, 2009; Powell, Bryne, \& Dailey, 2010; Prieger \& Hauge, 2010) and geographic location, with rural communities having limited access to the infrastructure that provides services (National Telecommunications and Information Administration, 2010; Strover, 2001).

Individual factors include the Internet's perceived relevance to one's life and work (Horrigan, 2010; National Telecommunications and Information Administration, 2010); an individual's level of education (National Telecommunications and Information Administration, 2010) and degree of digital literacy skills (Digital Impact Group, 2009; Horrigan, 2010; National Telecommunications and Information Administration, 2010), with lower levels of

\footnotetext{
${ }^{1}$ While other scholars, organizations, and community leaders working in the area of access and connectivity have been making this claim for some time, the UN report is groundbreaking in that it was the first such declaration by a multi-national organization with global power and reach.
} 
both negatively impacting broadband adoption. Most of these studies outlined above are quantitative and almost all of them highlight the intersection of age, race, and socio-economic status with these varying factors of non-adoption (Economics and Statistics Administration \& The National Telecommunications and Information Administration, 2010; Federal Communications Commission, 2010; Horrigan, 2009, 2010; Powell, Bryne, \& Dailey, 2010).

Digital divide research has also examined the monetary cost non-adoption has for individuals and households, as well as society more broadly. These studies situate people first and foremost as consumers by documenting the savings generated when people are able to compare prices online and tap into groupbuying offers through online marketplace websites such as Groupon and LivingSocial. Other research examines the larger societal costs when entire segments of the citizenry are not connected digitally (Horrigan, 2010) and the benefits that broadband access offers both individuals and society. One study by the Digital Impact Group and Econsult Corporation (2010) provides estimated annual costs of digital exclusion based on approximations of different categories of economic impact. From virtual monitoring of chronically ill patients to reduce hospital visits, to distance learning for continuing education to increase earnings and from telecommuting and virtual meetings to reduce travel costs, to increased access to information for exploring potential behavior modifications to conserve energy in the home and business - this study estimates the current total costs of digital exclusion to be over $\$ 55$ billion per year. ${ }^{2}$

The research outlined above has been helpful in mapping the digital divide, however when the issue of access is individualized using a "haves" vs. "have-nots" binary and when the benefits of access foreground the material costs of nonconnectivity, one can mistakenly associate economic marginalization in today's technology-rich society with non-connectivity alone. This is evident in many of the initiatives developed to bridge the digital divide, as much of the literature on Internet adoption increasingly and explicitly addresses "the relationship between skills acquisition and capacities to use the Internet to complete broader tasks (such as job searches)" (Dailey et al., 2010, p. 33).

\section{Digital, Social, and Economic Exclusion}

Much of the research on the digital divide and the resulting initiatives intended to bridge this divide, as summarized above, mask the very complicated ways in which digital exclusion both intersects with social and economic exclusion and also the ways that social and economic exclusion are further exacerbated by digital exclusion. As Eubanks (2011) argues, "the relationship between inequality and information technology (IT) is far more complex than any picture portraying 'haves' and 'have-nots' can represent' (p. 23). Recent qualitative and ethnographic scholarship provides evidence for Eubanks' position and offers a different lens through which to understand the digital divide and the

\footnotetext{
${ }^{2}$ Because in most cases the cost of digital exclusion cannot be directly observed and therefore must be inferred, the authors argue this report should be viewed as "providing an approximation of the scale of economic impact and as offering guidance on concepts worth further elaboration, analysis, and quantification" (p. i).
} 
many initiatives developed to bridge it. One such study by the Social Science Research Council (SSRC) (Dailey et al., 2010) was commissioned by the $\mathrm{FCC}^{3}$ to analyze the factors that shaped low rates of home broadband adoption in lowincome and other marginalized communities. ${ }^{4}$ While some of the broad findings of this study echo those from previous research on broadband access, others were more nuanced and some contradicted previous survey research findings entirely. For example, SSRC researchers found that broadband access is increasingly a requirement of social and economic inclusion, not simply an outcome of it, and that individuals from low-income and otherwise marginalized communities are well aware of this (Dailey, et al., 2010).

Unlike prior survey research on broadband adoption that finds nonadoption resulting from beliefs on individuals' perceived irrelevance of the Internet, the authors of this study found no such group. Researchers also found that costly monthly service fees are only one factor, and an insufficient one at that, in understanding barriers to access. Other factors include additional hardware and installation costs, unexpected and hidden billing fees and a lack of transparency in billing, and the quality of service and services available in lower income and communities of color. Study findings highlight the precariousness of access, a category researchers mark as "un-adoption," as households fluctuate between connectivity and cancellation of broadband services due to financial constraints, technical or billing issues, and the quality of services. These findings document access as fluid; they also frame the issue of access as a structural one by marking telecommunication companies' billing policies and the quality and reach of their networks as bearing responsibility for the variability of access. ${ }^{5}$

While the SSRC study argues for a national strategy to expand access to broadband as an approach that may serve to "break this relationship between digital exclusion and wider social and economic disadvantage" (Dailey et al., 2010, p. 6), we argue that increased connectivity alone among currently excluded groups will do little to address their social and economic marginalization. Access to, and use of, the Internet as a tool to access social services and employment in a market economy that increasingly offers fewer opportunities for family-sustaining employment to individuals without a postsecondary degree will do little to mediate social and economic marginalization.

\footnotetext{
${ }^{3}$ This study complimented a larger FCC study, which was a random phone survey of 5000 Americans, on broadband adoption designed to inform the National Broadband Plan.

4 This study was designed to compensate for two limitations of survey research: "underrepresentation and under-differentiation of marginalized communities in general phone surveys" (p. 9). The authors explain, "such difficulties have a number of sources, and in the nonadopter context may include the lower prevalence of landlines, lower English and/or technical literacy in some cases, and lower incentives to participate in surveys calibrated for groups with access to a broader spectrum of communication services. These factors can amplify the usual sensitivities of survey results to language and researcher assumptions" (p. 9). Qualitative research in partnership with those communities being studied can identify nuances that are difficult to recognize in broader survey research.

${ }^{5}$ Researchers found discrepancies between providers' claims of coverage and where coverage was actually available in lower income urban communities - an issue researchers marked as requiring further study.
} 
Other qualitative research provides additional evidence for our argument. Eubanks' (2011) participatory action research study of a technology-training program for women at a local YWCA in Troy, New York calls attention to the "myths and realities of the high-tech global economy for people who live in persistent poverty in the U.S." (p. xvi). Specifically, her research contradicts deeply entrenched "beliefs of technology policymakers and scholars: that lowincome people are technology poor, that technology training leads to sustainable employment, that women are more reluctant than men to engage with complex technological systems" (p. 24). Eubanks' study began from the assumption that "poor and working-class people already have vast experience with IT [Information Technology] and thus come to technology and social justice programs as knowledgeable and asset-bearing rather than deficient or needy ( $p$. 32) - a stance that prevented the study from reproducing the "prevailing wisdom" that position historically-marginalized women as "technology-poor" (p. 33).

Eubanks (2011) contrasts her own experiences with IT as "enriching the democratic process and expand[ing]...opportunities for a fulfilling and prosperous career" (p. 23) with those of the women in her study who have a "more complicated relationship to IT" (p.24). Of the women in her study, she writes:

In interviews and public events, many have said that they think "computers are the future," and have conceded that technological skills are something they should have to remain competitive in the job market. But they also directly experience the more exploitative face of IT as workers in low-wage, high-tech occupations such as data entry and call centers, as clients of increasingly computerized government services, and as citizens surveyed by technologies in public institutions and spaces. It is not so much that they lack access to technology but that their everyday experiences with it can be invasive, intrusive, and extractive. (p. 24)

One's relationship to structures of power in society deeply influences the experiences an individual has with digital technologies and the financial rewards they are able to receive from applying this knowledge/these skills in the workforce. The work of Eubanks (2011) and the women at the Troy YWCA provide evidence for this and challenge the popular belief that lower income communities are technology-poor, an idea implying those who have not benefited from the labor market, which is commonly believed to be all-providing and unproblematic, are alone to blame for their inability to reap its full rewards. Kvasny's (2006) qualitative study of a community technology center (CTC) offers further evidence for this same argument by documenting the structural gaps between participants' aspirations and the real probabilities for economic advancement and employment generated through participation in CTCs. In so doing, Kvasny demonstrates how "the benefits that one derives from ICT [information and communication technologies] are determined by two factors: the conditions in which the individuals acquired their ICT skills and the markets where these skills can be invested to derive profits" (p. 19). Kvasny argues these 
findings should inform designers of future initiatives to more broadly define the digital divide as an unequal ability to achieve life chances which include, but are not limited to, ICT access, and she argues that future initiatives should strike a balance between the interests of the community, municipal governments, and potential employers and should place participants in actual jobs. Kvasny \& Kiel (2005) come to a similar conclusion in their study on two different cities' approaches to addressing the digital divide. They argue the two municipal programs they examined "could be classified as successes in the sense that they provided access and basic computer literacy to people lacking these resources. However, both programs were, at least initially, conceived rather narrowly and represent short term, technology-centric fixes to a problem that is deeply rooted in longstanding and systemic patterns of spatial, political, and economic disadvantage" (p. 1).

\section{Poverty Scholarship}

Just as digital divide and digital literacy initiatives would benefit from examining how digital exclusion both intersects with and exacerbates social and economic exclusion, so too would this work benefit from a deeper understanding of poverty today. The connection between digital exclusion and broader patterns of social and economic exclusion is supported in part by scholarship described as New Poverty Studies (NPS). NPS maps the distinctive features of urban poverty in the late $20_{\text {th }}$ and early $21_{\text {st }}$ century and finds that "the conditions of U.S. poverty have changed in important ways" (Goode \& Maskovsky, 2001, p. 3-4). NPS scholarship identifies three interconnected processes that each further "the growing social and political disorder affecting the poor" (p. 4): market triumphalism at the ideological level, polarization at the economic level, and demobilization at the political level.

NPS scholarship positions urban poverty largely as the result of "the belief in the free market as the most efficient means for achieving economic growth and guaranteeing social welfare" (p. 7). Neoliberal policies and practices stemming from this belief promote the primacy of the market and individual self-interest, privatization, unrestricted flows of capital, deep reductions in the cost of labor, withdrawal of government from providing social welfare, and an emphasis on individual accountability at the expense of social responsibility (Harvey, 2005).

These policies and practices produce concentrations of urban poverty on the one hand, and areas of specialized and often globally-connected business activity on the other (Harvey, 2005; Davis, 2007). Goode and Maskovsky (2001) point out that while politicians and policymakers celebrate this "New Economy" driven by the global flow of finance, information, and technology" (p. 3), any acknowledgement of poverty, if it occurs, "is to bemoan the fact that the poor have been "left out"' (p. 3). Neoliberals, Shannon (2014) argues, understand poverty as "the lack of human capital sufficient to gain and maintain a sustainable income for oneself and one's family during rapidly changing times" (p. 99). New technologies, and one's ability (or inability) to capitalize on and work with them, play a central role in neoliberal understandings of the causes of poverty.

Yet NPS scholarship goes beyond an analysis of the knowledge and skills 
needed for employment in the 21 st century economy and instead demonstrates the significant ways in which poverty in the U.S. has changed over time. These scholars argue that today's "forms and distribution of postindustrial urban poverty are novel" because historically the poor "did not experience the same degree of segregation and isolation that exist today" and because large sectors of the population, especially young African Americans, are "detached from the mainstream economy, often outside of the labor market altogether" (Sugrue, 2005, p. 4; see also Katz, Stern, \& Fader, 2005). They also demonstrate how the economic restructuring and neoliberal policies that produce poverty affect not only the material well-being, but also the social relationships and political engagement of the poor (Goode \& Maskovsky, 2002).

NPS scholarship challenges the belief that poverty persists because of the pathology and welfare state dependency of the poor. Sociologist Matthew Desmond's (2015) groundbreaking scholarship also provides evidence that the very nature of poverty in the U.S. has changed, "especially at the very bottom" (p. 5) and also that poverty is more than a material condition (see also Desmond, 2016). His work is unique, however, in that he reveals poverty as a relationship and process that binds the rich and poor together. Desmond argues that structural accounts that fixate on what the poor lack - such as jobs, social services, and/or vocational training - obscure "the powerful ways in which exploitation contributes to the reproduction of urban poverty" (Desmond, 2015, p. 7). At its core, Desmond argues, "poverty is not simply an economic condition but the linked ecology of social maladies and broken institutions" and this "compounded adversity ... speaks to the clustering of different kinds of disadvantage across multiple dimensions (psychological, social, material) and institutions (work, family, prison)" (p. 3).

\section{Technology, Literacy, and Learning: Towards the Creation of a More Equitable Society}

\section{Technoutopianism and the (Digital) Literacy Myth.}

Scholarly research, as well as political and policy discourse, use various terms to describe the educational programs necessary to prepare individuals to participate in an increasingly technological and computer-driven society. What many of these terms have in common, however, is the use of the word "literacy." Digital literacy, computer literacy, and ICT and IT literacy are terms that reflect the skills-focused digital education initiatives directed towards non-adopters and employment seekers today. These types of initiatives tend to teach basic computer skills that are required to use the Internet to pursue continuing education opportunities, access social services, and connect with social media (Council of Economic Advisors, 2015; Rhinesmith, 2016; Warner \& Miller, 2012). They also teach digital literacy skills so that individuals may secure employment by going online to locate and apply for jobs and leverage their newly developed digital literacy skills to make them more attractive applicants for these jobs. We see these programs as flawed because they offer a decontextualized and partial understanding of digital, social, and economic exclusion that explicitly or 
implicitly positions access to, and basic familiarity with, ICT technology as singular tools to achieve broad-based economic and social equality.

The perception that technology - and most-recently information technology - can not only "level the playing field" and "create broad-based economic and social equality" but also "nurture transparency and accountability in democratic governance" (Eubanks, 2011, p. xv-Xvi) is a well-established and deeply held societal belief and value. Communications historian Eric Barnouw (1978) identifies this same conviction throughout the entire history of electronic media. He writes: "every step in modern media history - telephone, photograph, motion picture, radio, television, satellite - stirred similar euphoric predictions. All were expected to usher in an age of enlightenment. All were seen as fulfilling the promise of democracy" (p. 176; see also Mumford, 1967; for an analysis of the democratic potential mapped onto public radio and television, see Engelman, 1996; for an analysis of the democratic potential mapped onto cable access television, see Streeter 1987, 1996). Just as societal hopes for social change are mapped onto the broad use of technological tools, the acquisition of literacy - the practice of reading and writing - is similarly believed to be an indispensable precursor to social equity, democratic participation, and economic progress (Gee, 2008). That literacy is a tool for communication, and electronic and digital media platforms for this communication, may perhaps explain these mirrored values and expectations and their rootedness in democratic ideals, the achievement of which require both communication and dialogue.

The literacy historian Harvey Graff (1991) offers a useful lens for examining contemporary digital literacy initiatives and for understanding broader societal beliefs about the democratizing and equalizing power of literacy. First, Graff's research identifies what he terms as "the literacy myth," or a collection of beliefs about the power of literacy - both for an individual and larger society that he has shown through historical analyses to be incorrect, or at least stemming from a combination of other social factors rather than simple literacy levels alone. ${ }^{6}$ Graff's research on literacy campaigns in $19_{\text {th }}$ century Canada provides evidence that increasing levels of literacy did not correlate with increased social equality, democratic participation, or improved conditions for the working class.

${ }^{6}$ The Encyclopedia of Language and Education defines the "literacy myth" this way:

"Literacy Myth refers to the belief, articulated in educational, civic, religious, and other settings, contemporary and historical, that the acquisition of literacy is a necessary precursor to and invariably results in economic development, democratic practice, cognitive enhancement, and upward social mobility. Despite many unsuccessful attempts to measure it, literacy in this formulation has been invested with immeasurable and indeed almost ineffable qualities, purportedly conferring on practitioners a predilection toward social order, an elevated moral sense, and a metaphorical 'state of grace.' Such presumptions have a venerable historical lineage and have been expressed, in different forms, from antiquity through the Renaissance and the Reformation, and again throughout the era of the Enlightenment, during which literacy was linked to progress, order, transformation, and control. Associated with these beliefs is the conviction they can be attributed to other factors, whether economic, political, cultural, or individual. Rather, literacy stands alone as the independent and critical variable. Taken together, these attitudes constitute what Graff has called 'the Literacy Myth.' Many researchers and commentators have adopted this usage" (as cited in Graff, 2010, p. 635). 
By analyzing the processes of schooling and the acquisition of literacy among people of different ethnicities and in different occupational groups, Graff shows that no natural connection exists between schooling and social mobility. Rather, he finds "systemic patterns of inequality and stratification - by origins, class, sex, race, and age - were deep and pervasive, and relatively unaltered by the influence of literacy" and that "the social hierarchy was ordered more by the dominance of social ascription than by the acquisition of new, achieved characteristics" (p. xl), such as the acquisition of literacy. That is, the extent to which literacy provided an individual with an advantage in securing employment depended on their age, gender, and race or ethnicity; literacy did not exist as an independent variable or determining factor, but rather interacted with and mediated other social factors.

Second, Graff's (1991) research identifies how literacy was used as a tool for social control because "schooling in literacy was useful for the efficient training of the masses to the social order and the reassertion of hegemony" (p. 23). Individuals needed to be made literate in order to maintain the social order but because the teaching of reading and writing could be potentially radical and incendiary, policymakers severely controlled how literacy was taught to the underclass in order to ensure they did not use reading and writing to analyze their oppression and/or make demands for power (Gee, 1989). These "moral bases of literacy", Graff (1991) explains, are rooted in the "confluence of morality derivative of nondenominational Protestantism, with social change and the need for control" (p. 23) and they "accompanied the shift from a moral economy to a political economy in the late eighteenth and early nineteenth centuries" (p. 25). Graff explains:

Literacy...was expected to contribute vitally to the reordering and reintegration of the "new" society of the nineteenth century; it represented one central instrument and vehicle in the efforts to secure social, cultural, economic, and political cohesion in the political economy of the expanding capitalist order. (p. 25)

Literacy was a tool for social stability and hegemony in a time of great change and the teaching and practice of literacy through programs of formal education was "to teach and inculcate the rules for social and economic behavior in a changing and modernizing society" (Graff, 1991, p. 26). Graff's empirical evidence that highlights the role literacy played in sustaining capitalism and the status quo should be used in tandem with the body of scholarship on poverty identified above to complicate contemporary digital literacy initiatives and question commonly held beliefs about the power of connectivity and the acquisition and application of digital literacy skills to achieve social equity and lift people out of poverty.

When literacy is framed and practiced simply as a tool to find employment in a highly stratified capitalist society, it sustains such a society, and equality, or at least a disruption of the status quo is not possible. These beliefs and the intention that drives workforce-oriented digital literacy initiatives are incompatible with today's labor market that is highly-stratified and offers fewer 
opportunities for fulltime and stable employment at livable wages (Desmond, 2015; Konczal, 2016; McKee, 2008).

Literacy, as it has been framed and practiced over time and across different contexts, has been assigned infused with different purposes - from cultural and religious, to moral and emancipatory (Hamilton, 2016). "As a term," explains Hamilton (2016), "literacy is elastic and slippery and it can be made to carry all kinds of hopes, judgements and expectations" (p. 3). Across these years and contexts, literacy has been employed in the service of nation-building, the production of wealth, and human rights (Hamilton, 2016). However, because literacy, at its root, involves the ability to decode and reproduce written or printed text "neither writing nor printing per se are 'agents of change'; their impacts are determined by the manner in which human being exploit them" (Graff, 1982, p. 13). If, as we argue, many literacy education initiatives for workforce development are insufficient to interrupt the cycle of poverty - which poverty scholarship shows to be part and parcel of broader structural and social processes and are not easily mediated by solutions that address only one part of a more complex whole - then what is to be done? How might one work towards creating an equitable society and what role might technology or literacy or education more broadly play in this work?

\section{Literacy, Learning, and Social Change}

Scholars whose work is foundational to the field of literacy studies and critical education studies offer a framework for understanding how reading and writing can be used as tools by marginalized individuals to identify, understand, and work towards dismantling systems and policies of oppression (Freire, 1994; Giroux, 1988). According to Freire (1994), liberation from oppression involves praxis, or "the action and reflection of men and women upon their world in order to transform it" (p. 60) and literacy - the practice of reading and writing - plays a central role in this work. Freire's (1987) framing of reading, in particular, underscores the role of human experience in the process of making sense of written language. He explains:

Reading does not consist merely of decoding the written word or language; rather it is preceded by and intertwined with knowledge of the world. Language and reality are dynamically interconnected. The understanding attained by critical reading of a text implies perceiving the relationship between text and context. (p. 29)

This engagement involves the critical interpretation of text and larger world in order to act upon this world, or as Freire (1987) explains "to rewrite[e] what is read" (p. 36).

The fields of critical literacy and media literacy, as bodies of research and critical educational practices, offer important frameworks for understanding the intersection of language and power (Janks, 2010; Janks, Dixson, Ferreira, Granville \& Newfield, 2014) and how and why to read critically in an increasingly mediated world (boyd, 2017; Buckingham, 2003; Hobbs \& Jensen, 
2009; Jenkins, Purushotma, Weigel, Clinton, \& Robison, 2009; Masterman, 1985). We acknowledge the diverse richness of the scholarship and practice in these fields and, in particular, the critical and media literacy work done with and by youth (see, for example Cammarota \& Fine, 2008; Cox, 2015; Ewald, Hyde, \& Lord, 2011; Goodman, 2003; Soep \& Chávez, 2010). It is important to note, however, that schools are mostly not places where this kind of literacy learning takes place.

One need look no further than under-resourced schools that predominantly serve poor and historically marginalized students of color that are burdened by state and federal educational policies that mandate the standardization of knowledge and accountability for academic achievement as determined by students' scores on high-stakes, standardized tests (Lipman, 2008, 2011) even though a great deal of research documents the different ways in which "highstakes tests create negative, unintended consequences which disproportionately impact students from racial minority, language minority, and low socioeconomic backgrounds" (Amrein \& Berliner, 2002, p. 10). Additionally, the narrow, rote, and decontextualized engagements with literacy advanced by these statemandated accountability policies "carry within them values of quiescence and placidity, values that will ensure no real demands for significant social change" (Gee, 2008, p. xiv). Truly transformational literacy practices are those that involve more than skills-based literacy instruction with reading and writing as end goals in and of themselves, rather they employ literacy as a tool to engage in meaningful acts and participate in the broader world.

Critical research on education and schooling overwhelmingly documents how schools - as places where formal literacy instruction is practiced - are sites for socialization and mostly reproduce inequalities rather than interrupt the status quo (for an excellent overview of research documenting schools and classrooms as sites for economic, cultural, and linguistic reproduction, see Collins, 2009). While some scholarship on social reproduction has been criticized for its rigid structural analysis that ignores individual agency and identity (a discussion of which is beyond the scope of this paper), as a body of scholarship it is important to consider here because it complicates popular beliefs about the potential for schooling, and literacy as practiced in schools, to create broad-based social equity. Research by educational historians calling attention to "the extraordinary reliance federal social policy has placed on education as a solution to issues of poverty and economic distress in the years since the Great Society" (Kantor \& Lowe, 2016, p. 37) reinforces this point. Schooling is now centrally and singularly positioned as the tool to alleviate poverty because schools develop the human capital needed to compete and secure employment in a stratified labor market. Kantor and Lowe argue that while schooling does create individual opportunities, it does not create broad-based equity.

In her analysis juxtaposing learning with schooling or education, Patel (2016) argues that "formal education demands mastery for the promised purpose of success, but more regularly delivers on the implicit purpose of stratification" while "learning demands a transformation of oneself for impacts and consequences that are fundamentally unpredictable" (p. 399). Patel argues that 
learning is marronage, or "a practice of freedom that must, necessarily, start from the condition and category of enslavement in order to transgress it" (p. 400). While Patel's understanding of learning extends beyond the tools people use to make meaning (i.e. reading and writing) and is not limited to social transformation alone, her positioning of learning as disruptive, unpredictable, and transformational in combination with Freire's $(1987,1994)$ scholarship and practice on literacy as a tool to transform societies provide a powerful framework for understanding how literacy can be an agent of change. Only when reading and writing are used to as tools for learning, and when they are employed to question the status quo, to devise solutions for solving social problems, and to participate actively and critically in communities in ways to solve these problems, can literacy, or the technological tools used to engage in literate practices, be true agents of change (see also Fraser's [2010] discussion of redistribution, recognition, and representation for a framework theorizing justice).

While a robust discussion of those organizations, programs, and scholarship offering examples of transformational critical and digital literacy work is beyond the scope of this paper, we believe it is important to conclude by pointing readers towards some of this important work. Scholarship on critical youth development centers the sociopolitical development of youth of color and youth organizing as tools for both youth and community development and also to develop larger social movements that demand and work towards social equity in different ways (see Ginwright \& Cammarota, 2007; Ginwright, Cammarota, \& Noguera, 2005; Ginwright \& James, 2002; Kirshner \& Ginwright, 2012). This work challenges deficit-centered understandings of youth by highlighting the collective agency of young people as they work to create change in their communities through organizing and advocacy work.

In Philadelphia, the media justice organization Media Mobilizing Project (MMP) works to harnesses media to build on the power of communities fighting for justice and equity in the region (see Funke, Robe and Wolfson, 2012; Wolfson \& Funke 2013). In 2011, MMP established the Media Institute, which primarily recruits among organizers and social justice activists in the region and has a threefold focus: to offer a broader political and economic analysis of the region, to train attendees in media production skills they can bring back to their communities, and to offer people the skills and access to use the Internet in ways that matter for their everyday lives and their communities. The Media Institute has been successful because it directly links the digital divide to media production and strategies for harnessing the web to tell and share stories and advocate for change on issues people are organizing around - from the economy, to criminal justice, to public education.

\section{Conclusion}

Poverty scholar Matthew Desmond (2015) argues that, "thinking that one institution or condition has supreme explanatory priority - that 'the most important thing' is the family, the neighborhood, housing, employment, or education - may be the wrong direction for poverty research" a point, he

maintains, "applies to statistical methods that promote isolationist thinking as well 
as to qualitative approaches that tend to focus on a single dimension of a disadvantaged group instead of "studying the whole"' $(2015$, p. 4).

Like poverty, digital exclusion is part and parcel of broader structural and social processes and is not easily understood by research, or mediated by solutions, that address what is a symptom of a larger and more complex problem. The primarily quantitative research on the digital divide reviewed in the beginning of this paper is helpful in mapping the landscape of access, but less so for understanding the very nature of digital exclusion and the ways in which digital, social, and economic exclusion intersect and reinforce each other - an understanding, we argue, that is essential for scholars of the digital divide. The Digital Jobs Fair in Philadelphia that introduced this paper was developed and executed based on the assumption that the digital divide is the fundamental problem. We argue, however, that the digital divide is not the problem, rather it is a symptom of social and economic marginalization that has been exacerbated by policies and practices that further disenfranchise poor and working people. Initiatives that aspire to lift people out of poverty by providing them broadband access and training in digital literacy fail because they misunderstand the nature of poverty today by aiming to solve a symptom of a much larger and more complicated problem, rather than the problem itself.

The qualitative research on digital exclusion reviewed in this paper - some of it participatory action research, which includes members of a community being studied in the design and execution of that study and later in analyzing the study's findings - offers a more nuanced and complex understanding of the digital divide. This scholarship does not position individuals without access or digital literacy skills as lacking or digitally illiterate, rather it draws from individual and community knowledge and experience to highlight the shortcomings of the labor market and the often-exploitative jobs in the field of IT that are available to individuals without a postsecondary education. Technology, this scholarship documents, is not the herald of social justice and equity it is claimed to be. And as with technology, historical scholarship on literacy and critical education scholarship similarly debunks widely-held beliefs about the potential for literacy alone to interrupt the cycle of poverty and create widespread social parity. This interdisciplinary research, we argue, offers essential insights that can and should inform digital divide research and digital literacy initiatives that look to access and the acquisition of IT skills alone as reliable pathways to employment and out of poverty.

This highlights a "serious" misconception in the field of ICT studies: "the belief that democracy is first and foremost a matter of distributing information" (Winner as cited in Dunbar-Hester, 2009, p. 233). Democracy is not simply the distribution of information, but the connection of individuals with likeminded interests and the political mobilization and civic engagement of these individuals around focused work towards change that can transform society. The information economy does offer new tools that can lead to building power of working people. Tools like the Internet can play a role in breaking isolation and alienation by connecting marginalized groups and individuals and by providing platforms, spaces, and education for political and civic engagement and action but only if 
these tools are grounded in the real material needs of working people and are geared towards those needs.

Neither digital education nor broadband access alone can promote a more equitable society. Rather, it is the critical engagement by and with individuals and groups on issues of social importance and worth (such as, but not limited to, the right to a living wage, workers' rights, the fight against violence inflicted on communities of color by the state, immigrant/migrant/refugee rights, the right to quality education and health care, the right to a clean environment and safe drinking water, the need for more government oversight on corporate and business activities, the fight against gender-based violence, and the right to affordable housing) and the role of new information technologies in fostering this critical engagement and mobilization that can lead to concrete changes that improve the lives and working conditions of marginalized individuals and communities.

\section{References}

Amrein, A.L. \& Berliner, D.C. (2002, December). An analysis of some unintended and negative consequences of high-stakes testing. Education Policy Studies Laboratory, Arizona State University. Retrieved from http://nepc.colorado.edu/files/EPSL-0211-125-EPRU.pdf

Barnouw, E. (1978). The sponsor: Notes on a modern potentate. New York, NY: Oxford University Press.

boyd, d. (2017). Spotlight: Did media literacy backfire? Journal of Applied Youth Studies, 1(4), 83-89.

Buckingham, D. (2003). Media education: Literacy, learning and contemporary culture. Malden, MA: Polity Press.

Cammarota, J. \& Fine, M. (2008). Revolutionizing education: Youth participatory action research in motion. New York, NY: Routledge.

Collins, J. (2009). Social reproduction in classrooms and schools. Annual Review of Anthropology, 38, 33-48.

Cooper, M. (2010). The challenge of digital exclusion in America: A review of the social science literature and its implications for the U.S. National Broadband Plan. Washington, D.C.: Consumer Federation of America.

Council of Economic Advisers. (2015, July). Mapping the digital divide. (Issue Brief). Washington, D.C.

Cox, A.M. (2015). Shapeshifters: Black girls and the choreography of citizenship. Durham, NC: Duke University Press.

Crowell, J.K. (2017). Liquid labor, precarious lives: An urban ethnography on online work and digital inequality. (Unpublished doctoral dissertation). Rutgers University, New Brunswick, NJ.

Dailey, D., Bryne, A., Powell, A., Karaganis, J., \& Chung, J. (2010). Broadband adoption in low-income communities. The Social Science Research Council: New York, NY. Retrieved from http://www.ssrc.org/publications/view/1EB76F62-C720-DF11-9D32001CC477EC70/

Davis, M. (2007). Planet of slums. New York, NY: Verso. 
Desmond, M. (2015). Severe deprivation in America: An introduction. The Russell Sage Foundation Journal of the Social Sciences, 1(1), 1-11.

Desmond, M. (2016). Evicted: Poverty and profit in the American city. New York, NY: Crown Publishers.

Digital Impact Group (2009, December 2). Comments on the National Broadband Plan, Federal Communications Commission GN Docket 09-47.

Digital Impact Group and Econsult Corporation (2010). The economic impact of digital exclusion. Philadelphia, PA: Econsult Corporation.

Dunbar-Hester, C. (2009). 'Free the spectrum!': Activist encounters with old and new media technology. New Media and Society, 11, 221-240.

Economics and Statistics Administration and The National Telecommunications and Information Administration (2010). Exploring the digital nation: Home broadband Internet adoption in the United States. Retrieved from http://www.ntia.doc.gov/report/2010/exploring- digital-nationhomebroadband-internet-adoption-united-states

Engelman, R. (1996). Public radio and television in America: A political history. Thousand Oaks, CA: Sage Publications.

Eubanks, V. (2011). Digital dead end: Fighting for social justice in the information age. Cambridge, MA: MIT Press.

Ewald, W., Hyde, K., \& Lord, L. (2011). Literacy and justice through photography: A classroom guide. New York, NY: Teachers College Press.

Federal Communications Commission (2010). National broadband plan: Connecting America. Retrieved from http://www.broadband.gov/plan/

Fraser, N. (2010). Scales of justice: Reimagining political space in a globalizing world. New York, NY: Columbia University Press.

Freire, P. (1987). The importance of the act of reading. In P. Freire \& D. Macedo (Eds.), Literacy: Reading the word and the world (pp. 29-37). South Hadley, MA: Bergin \& Garvey.

Freire, P. (1994). Pedagogy of the oppressed. New York, NY: Continuum.

Funke, P., Robe, C., \& Wolfson, T. (2012) Suturing working class subjectivities and the role of media in building a class-based social movement. tripleC: Communication, Capitalism and Critique, 10(1), 16-29.

Gee, J.P. (1989). Orality and literacy: From 'The Savage Mind' to 'Ways with Words'. Journal of Education, 171(1), 39-60.

Gee, J.P. (2008). Social linguistics and literacies (3rd ed.). New York, NY: Routledge.

Ginwright, S. \& Cammarota, J. (2007). Youth activism in the urban community: Learning critical civic praxis within community organizations. International Journal of Qualitative Studies in Education, 20(6), 693710.

Ginwright, S., Cammarota, J., \& Noguera, P. (2005). Youth, social justice, and communities: Toward a theory of urban youth policy. Social Justice, 32(3), 24-40.

Ginwright, S. \& James, T. (2002). From assets to agents of change: Social justice, organizing, and youth development. New Directions for Youth 
Development, 96, 27-46.

Giroux, H. (1988). Literacy and the pedagogy of voice and political empowerment. Educational Theory, 38(1), 61-75.

Goode, J. \& Maskovsky, J. (Eds.). (2001). The new poverty studies: The ethnography of power, politics and impoverished people in the United States. New York, NY: New York University Press.

Goodman, S. (2003). Teaching youth media: A critical guide to literacy, video production and social change. New York, NY: Teachers College Press.

Graff, H.J. (1982). The legacies of literacy. Journal of Communication 32(1), 12 26.

Graff, H.J. (1991). The literacy myth: Cultural integration and social structure in the nineteenth century. New Brunswick, NJ: Transaction Publishers.

Graff, H.J. (2010). The Literacy Myth at thirty. Journal of Social History, 43(3), 635-661.

Hamilton, M. (2016). Imagining literacy: A sociomaterial approach. In K. Yasukawa \& S. Black (Eds.), Beyond economic interests: Critical perspectives on adult literacy and numeracy in a globalized world (pp. 3-17). Boston, MA: Sense Publishers.

Harvey, D. (2005). A brief history of neoliberalism. New York, NY: Oxford University Press.

Hobbs, R. \& Jensen, A. (2009). The past, present, and future of media literacy education. Journal of Media Literacy Education 1(1), 1-11.

Horrigan, J.B. (2009). Home broadband adoption 2009: Pew Internet and American Life Project. Retrieved from http://www.pewinternet.org/Reports/2009/10-Home-BroadbandAdoption-2009.aspx

Horrigan, J.B. (2010). Broadband adoption and use in America. Federal Communications Commission Omnibus Broadband Initiative Working Paper Series No. 1. Retrieved from www.fcc.gov/DiversityFAC/032410/consumer-survey-horrigan.pdf

Janks, H. (2010). Literacy and power. New York, NY: Routledge.

Janks, H., Dixon, K., Ferreira, A., Granville, S., Newfield, D. (2014). Doing critical literacy: Texts and activities for students and teachers. New York: Routledge.

Jenkins, H., Purushotma, R., Weigel, M., Clinton, K., Robison, A.J. (2009). Confronting the challenges of participatory culture: Media education for the $21_{\text {st }}$ century. Cambridge, MA: MIT Press.

Kantor, H. \& Lowe, R. (2016). Educationalizing the welfare state and privatizing education: The evolution of social policy since the New Deal. In W.J. Mathis \& T.M. Trujillo (Eds.), Learning from federal market-based reforms: Lessons for ESSA (pp. 37-60). Charlotte, NC: Information Age Publishing, Inc.

Katz, M.B. (2008). The price of citizenship: Redefining the American welfare state. Philadelphia, PA: University of Pennsylvania Press.

Katz, M.B., Stern, M.J., \& Fader, J.J. (2005). The new African American inequality. The Journal of American History, 92(1), 75-108. 
Kirshner, B. \& Ginwright, S. (2012). Youth organizing as a developmental context for African American and Latino adolescents. Child Development Perspectives, 1-7.

Konczal, M. (2016, December 28). Trump is capitalizing on the anxiety caused by the end of steady employment: Liberals should speak to workers' experience of precarity. The Nation. Retrieved from https://www.thenation.com/article/trump-is-capitalizing-on-theanxietycaused-by-the-end-of-steady-employment/

Kvasny, L. (2006). Cultural (re)production of digital inequality in a U.S. community technology initiative. Information, Communication, \& Society,9(2), 160-181.

Kvasny, L. \& Kiel, M. (2005). The challenges of redressing the digital divide: A tale of two cities. Information Systems Journal, 16(1) 23-53.

La Rue, F. (2011). Report of the Special Rapporteur on the promotion andprotection of the right to freedom of opinion and expression. New York: United Nations. Retrieved from http://www2.ohchr.org/english/bodies/hrcouncil/docs/17session/A.HRC .17 .27 en.pdf

Lipman, P. (2008). Education policy, race, and neoliberal urbanism. In S. Greene (Ed.), Literacy as a civil right: Reclaiming social justice in literacy teaching and learning (pp. 45-66). New York, NY: Peter Lang.

Lipman, P. (2011). The new political economy of urban education: Neoliberalism, race, and the right to the city. New York, NY: Routledge.

Masterman, L. (1985). Teaching the media. New York, NY: Comedia Publishing Group.

McKee, D.L. (2008). Services, growth poles, and advanced economies. Service Business, 2(2), 99-107.

Mosco, V. (2005). The digital sublime: Myth, power and cyberspace. Cambridge: MIT Press.

Mumford, L. (1967). The myth of the machine: Technics and human development. New York, NY: Harcourt Brace Jovanovich, Inc.

National Telecommunications and Information Administration (2010). Digital nation: 21 st century America's progress toward universal broadband Internet access. Washington, DC: U.S. Department of Commerce.

Patel, L. (2016). Pedagogies of resistance and survivance: Learning as marronage. Equity \& Excellence in Education, 49(4), 397-401.

Pew Charitable Trusts (2013). Philadelphia 2013: The state of the city. The Pew Charitable Trusts. Retrieved from http://www.pewtrusts.org/ /media/legacy/uploadedfiles/wwwpewtrustso rg/reports/philadelphia_research_initiative/philadelphiacitystatisticspdf.p df

Pew Charitable Trusts (2016). Philadelphia: The state of the city: A 2016 update. The Pew Charitable Trusts. Retrieved from http://www.pewtrusts.org/ /media/assets/2016/03/philadelphia_the_state of the city 2016.pdf

Powell, A., Bryne, A., \& Dailey, D. (2010). The essential Internet: Digital 
exclusion in low-income American communities. Policy \& Internet, 2(2), 161-192.

Prieger, J. \& Hauge, J.A. (2010). Demand-side programs to stimulate adoption of broadband: What works? Pepperdine University, School of Public Policy Working Papers. Paper 15. Retrieved from http://digitalcommons.pepperdine.edu/sppworkingpapers/15

Rhinesmith, C. (2016). Digital inclusion and meaningful broadband adoption initiatives. Evanston, IL: Benton Foundation.

Soep, E. \& Chávez, V. (2010). Drop that knowledge: Youth radio stories. Berkeley, CA: University of California Press.

Shannon, P. (2014). Reading poverty in America. New York, NY: Routledge.

Streeter, T. (1987). The cable fable revisited: Discourse, policy, and the making of cable television. Critical Studies in Mass Communication, 4, 174-200.

Streeter, T. (1996). Selling the air: A critique of the policy of commercial broadcasting in the United States. Chicago, IL: University of Chicago Press.

Strover, S. (2001). Rural Internet connectivity. Telecommunications Policy, 25(5), 331-347.

Sugrue, T.J. (2005). The origins of the urban crisis: Race and inequality in postwar Detroit. Princeton, NJ: Princeton University Press.

Warner, F. \& Miller, J. (2012). Connect Detroit: Lessons from one city's efforts to bridge the digital divide. Miami, FL: Knight Foundation. Retrieved from http://www.knightfoundation.org/media/uploads/publication_pdfs/13832 KF_Report_ConnectDetroit_4-4.pdf

Wolfson, T., Crowell, J., Reyes, C., \& Bach, A. (2017). Emancipatory broadband adoption: Toward a critical theory of digital inequality in the urban United States. Communication, Culture and Critique, 10, 441-459.

Wolfson, T. \& Funke, P. (2013). Communication, class and concentric media practices: Developing a contemporary rubric. New Media and Society, 16(3), 363-380. 